\title{
Preface: Restoration, biogeochemistry and ecological services of wetlands
}

\author{
Dominik Zak • Robert McInnes • Jörg Gelbrecht
}

Published online: 9 June 2011

(C) Springer Science+Business Media B.V. 2011

Natural wetlands, including fens, shallow lakes and floodplains, provide many benefits to society (Costanza et al., 1997). In particular, these wetlands deliver important functions as long-term sinks for nutrients and carbon, as hydrological buffers, and as habitats for many endangered plant and animal species (Millennium Ecosystem Assessment, 2005). In the face of eutrophication of watercourses, decreasing biodiversity, and expected climate changes, the importance of these multi-functional wetlands is being recognized more and more (McInnes, 2011). Currently, there are international efforts to protect wetlands or to repair their functions in the landscape through restoration measures (Erwin, 2009). However, their ecological rehabilitation has long been based on trial and error. Increasingly knowledge of the biogeochemical drivers of natural and biodiverse wetlands, and how these pertain to

Guest editors: Dominik Zak, Robert McInnes, Jörg Gelbrecht / Restoration, biogeochemistry and ecological services of wetlands

D. Zak $(\bowtie) \cdot$ J. Gelbrecht

Leibniz-Institute of Freshwater Ecology and Inland Fisheries, Central Chemical Laboratory, Müggelseedamm 301, 12587 Berlin, Germany

e-mail: zak@igb-berlin.de

R. McInnes

Bioscan (UK) Ltd., The Old Parlour, Little Baldon Farm, Oxford OX44 9PU, UK successful restoration, is vital in order to prevent costly operations with an unpredictable outcome (Klötzli \& Grootjans, 2001). With relevant knowledge the restoration outcomes can be forecasted and choices should, therefore, be based on the actual restoration potential of an area rather than on the reconstruction of the prior ecosystem (van Diggelen et al., 2001). This approach requires information on causal relations and therefore experiments and investigations at different scales are of pivotal importance. Successful restoration of wetlands calls for interdisciplinary experimental research in which ecology, hydrology, microbiology, and geochemistry merge into a system-ecological approach. Furthermore, different scientific disciplines must be integrated with wetland managers, stakeholders, and crosssectoral government agencies throughout all stages of wetland restoration (from objective setting to postrestoration monitoring), in order to optimize restoration measures (Trepel, 2007).

Embracing this approach, the 4th Annual Meeting of the European Chapter of the Society of Wetland Scientists (SWS) was held between 20th and 24th of May 2009 in Erkner, near Berlin, both scientists and practitioners came together to share their knowledge. The SWS is a $3500+$ member organisation that promotes scientific understanding, scientificallybased management and sustainable use of wetlands. Under the theme "Progress and problems in wetland science-with a particular focus upon wetland restoration in Europe", the 4th Annual Meeting attracted 
75 people from 21 countries. During the Annual Meeting different issues concerning restoration, biogeochemistry and the ecosystem services of wetlands were discussed within the scope of two main topics (1) "Nutrient retention and carbon cycle in restored European wetlands" and (2) "Vegetation in wetlands and water treatment". Thus, this volume of Hydrobiologia contains a selection of 12 per-reviewed and edited papers which span a broad range of wetland topics and are introduced briefly below.

\section{Nutrient retention and carbon cycle in restored European wetlands}

Within the first topic, experiences with wetland restoration projects in Central Europe were reported focusing on nutrient and carbon cycles. Monitoring strategies from four different stream and wetland restoration projects in Denmark were compared and evaluated with respect to hydrology, i.e. flow pattern and discharge of ground or surface water and retention of phosphorus and removal of nitrogen (Hoffmann et al., 2011). When severely degraded fens are restored by rewetting, they often become shallow lakes with an average water depth of less than $1 \mathrm{~m}$. The high nutrient availability in highly decomposed peat soils of these rewetted ecosystems favour the fast establishment of a small number of helophytes, while the return of lost target species like low sedges and brown mosses could be delayed for decades (Zak et al., 2010). To obtain knowledge on the optimal management of helophytes in restoration practice a study was conducted demonstrating how the water level, seasonality and different dominating helophytic species (Carex riparia, Glyceria maxima, Phalaris arundinacea, Phragmites australis, and Typha latifolia) are crucial factors for biomass production, nutrient standing stock, and litter accumulation in inundated fen grasslands of North East Germany (Schulz et al., 2011). An investigation of the silicon uptake by riparian vegetation with reference to nitrogen $(\mathrm{N})$ and phosphorus $(\mathrm{P})$, under contrasting moisture and management conditions, reveals a clearer understanding of the impact of riparian vegetation on nutrient transport. This can be an important consideration within restoration projects as riparian planting is often advocated a measure to moderate excessive $\mathrm{N}$ and $\mathrm{P}$ inputs into the rivers
(Struyf et al., 2011). Peatlands in Central Europe have been drained and degraded for centuries, primarily for fuel or for agricultural purposes. This has allowed oxygen to penetrate the remaining peat causing the organic material that has built up over the course of millennia to begin to decompose, releasing the greenhouse gas (GHG) carbon dioxide. Therefore, the restoration of degraded peatlands has been promoted to mitigate gaseous and aquatic carbon losses, however, there are conflicting reports as to the effectiveness of this approach. Fenner et al. (2011) report field-scale "hotspots" of organic matter decomposition as a result of rewetting a drained peatland in Wales, which over the medium/long-term have implications for water quality and $\mathrm{GHG}$ emissions.

Vegetation seems well qualified for indicating GHG fluxes from peat soils as it reflects long-term hydrological regime, affects GHG emissions via assimilate supply and aerenchyma, and allows finescaled mapping. An example of a methodology employed to assess emissions and emission reductions from peatland rewetting projects using vegetation as a proxy is presented from two Belarussian peatlands (Couwenberg et al., 2011).

It is clear that peatland restoration could impact the interests of a broad range of local and regional stakeholders and potentially generate substantial socio-economic consequences. Arguably, farmers and land owners would have to bear the costs of adaptation and currently the mechanism for compensation are not clear. Against this background, Schaller et al. (2011) unravelled the question how either social benefits can be monetarised in order to finance climate-friendly peatland-cultivation strategies or common instruments of agricultural politics can be used to subsidise farmers' losses.

\section{Vegetation in wetlands and water treatment}

Ecological restoration of degraded European wetlands is important, but the conservation of the remaining natural peatlands is paramount for both biodiversity and the ecosystem services they provide. However, our understanding of the functioning of intact or pristine systems is still lacking, with the majority of studied sites being to some extent degraded. Jablonska et al. (2011) describe the relationship between 
vegetation patterns, hydrochemical gradients, and water level fluctuations carried out in the Rospuda valley (North East Poland), which was recently discovered as an uniquely-preserved, fully functioning percolation mire.

Plants comprise multiple interacting traits. The correlation among these traits can affect how quickly or even whether populations of invasive plants adapt to their local climatic conditions. It has been shown that multivariate techniques represent a more useful approach when investigating the formation of latitudinal clines in invasive populations of Lythrum salicaria (purple loosestrife) than using univariate methods alone (Edwards et al., 2011).

Due to their well-known nutrient removal capabilities, different wetland plants are used in constructed wetlands to purify wastewater. The macrophytes growing in constructed wetlands have several properties in relation to the treatment process that make them an essential component of the design. The review of Vymazal (2011) demonstrates that macrophytes utilised within constructed wetlands with horizontal subsurface flow should (1) be tolerant of high organic and nutrient loadings, (2) have rich belowground organs (i.e., roots and rhizomes) in order to provide a substrate for attached bacteria and oxygenation of areas adjacent to roots and rhizomes, and (3) have high aboveground biomass for winter insulation in cold and temperate regions and for nutrient removal via harvesting. Floating treatment wetlands represent a degree of innovative in water purification, however their processes are still scarcely known when compared to the traditional methods of phytodepuration. To gain initial information on their performance and potential for removing pollutants an experimental survey has been conducted in North East Italy in a Natural Park with resurgent water (De Stefani et al., 2011). In addition to their nutrient removal capabilities some wetland plants are able to absorb heavy metals in high concentrations. Highly industrialized estuaries often receive a large input of heavy metals which are accumulated in salt marsh sediments. For instance, Spartina maritima, the most abundant plant species in the Portuguese salt marshes was tested in conjunction with applicated low molecular weight organic acids, in order to evaluate their effectiveness for phytoremediation processes (Duarte et al., 2011).

As part of the Baltic Sea Action Plan, the construction of wetlands has been suggested as a measure to reduce the transport of $\mathrm{P}$ from agricultural land to aquatic ecosystems (HELCOM, 2007). In this context, a constructed wetland in South East Sweden, densely colonized by $T$. latifolia, was investigated with respect to $\mathrm{P}$ retention based on inflow-outflow measurements compared with the amount of $\mathrm{P}$ accumulated in the newly formed sediment (Johannesson et al., 2011).

The papers presented at the 4th Annual Meeting of the European Chapter of the SWS, and published herein, represent a component of a much larger body of wetland scientific research. Often the non-market values of wetland ecosystem services have excluded them from important decision-making processes whilst wetland restoration has primarily been driven by nature conservation interests. The scientific results presented here contribute to demonstrating that the restoration of wetland ecosystems can generate palpable benefits for society through a range of mechanisms such as improving water quality or mitigating climate change. Thus, the wetland scientific community, through bodies such as the Society of Wetland Scientists, needs to continue to engage with wetland managers, stakeholders and across government departments to ensure that wetland restoration is informed by good science and that the breadth of ecosystem services provided by wetlands are optimised for the benefit of society.

\section{References}

Costanza, R., R. d'Arge, R. de Groot, S. Farber, M. Grasso, B. Hannon, K. Limburg, S. Naeem, R. V. O’Neill, J. Paruelo, R. G. Raskin, P. Sutton \& M. van den Belt, 1997. The value of the world's ecosystem services and natural capital. Nature 387: 252-259.

Couwenberg, J., A. Thiele, F. Tanneberger, J. Augustin, S. Bärisch, D. Dubovik, N. Liashchynskaya, D. Michaelis, M. Minke, A. Skuratovich \& H. Joosten, 2011. Assessing greenhouse gas emissions from peatlands using vegetation as a proxy. Hydrobiologia. doi:10.1007/s10750-011-0729-x

De Stefani, G., D. Tocchetto, M. Salvato \& M. Borin, 2011. Performance of a floating treatment wetland for in-stream water amelioration in NE Italy. Hydrobiologia. doi: 10.1007/s10750-011-0730-4

Duarte, B., J. Freitas \& I. Caçador, 2011. The role of organic acids in assisted phytoremediation processes of salt marsh sediments. Hydrobiologia. doi:10.1007/s10750-011-0731-3

Edwards, K. R., D. Bastlová, M. Edwards-Jonášová \& J. Květ, 2011. A comparison of univariate and multivariate methods for analyzing clinal variation in an invasive species. Hydrobiologia. doi:10.1007/s10750-011-0732-2 
Erwin, K. L., 2009. Wetlands and global climate change: the role of wetland restoration in a changing world. Wetlands Ecology Management 17: 71-84.

Fenner, N., R. Williams, H. Toberman, S. Hughes, B. Reynolds \& C. Freeman, 2011. Decomposition 'hotspots' in a rewetted peatland: implications for water quality and carbon cycling. Hydrobiologia. doi:10.1007/s10750-0110733-1

HELCOM, 2007. The Baltic Sea Action Plan. HELCOM Ministerial Meeting, Krakow, Poland.

Hoffmann, C. C., B. Kronvang \& J. Audet, 2011. Evaluation of nutrient retention in four restored Danish riparian wetlands. Hydrobiologia. doi:10.1007/s10750-011-0734-0

Jablonska, E., P. Pawlikowski, F. Jarzombkowski, J. Chormański, T. Okruszko \& S. Kłosowski, 2011. Importance of water level dynamics for vegetation patterns in a natural percolation mire (Rospuda fen, NE Poland). Hydrobiologia. doi:10.1007/s10750-011-0735-Z

Johannesson, K. M., J. L. Andersson \& K. S. Tonderski, 2011. Efficiency of a constructed wetland for retention of sediment associated phosphorus. Hydrobiologia. doi: 10.1007/s10750-011-0728-y

Klötzli, F. \& A. P. Grootjans, 2001. Restoration of natural and semi-natural wetland systems in central Europe: progress and predictability of developments. Restoration Ecology 9: 209-219.

McInnes, R. J., 2011. Managing wetlands for multi-functional benefits. In Le Page, B. A. (ed.), Wetlands-Integrating Multidisciplinary Concepts. Springer, Dordrecht.

Millennium Ecosystem Assessment, 2005. Ecosystems and Human Health: Water and Wetlands Synthesis. World Resources Institute, Washington: $68 \mathrm{pp}$.
Schaller, L., J. Kantelhardt \& M. Drössler, 2011. Cultivating the climate: socio-economic prospects and consequences of climate-friendly peatland management in Germany. Hydrobiologia. doi:10.1007/s10750-011-0736-y

Schulz, K., T. Timmermann, P. Steffenhagen, S. Zerbe \& M. Succow, 2011. The effect of flooding on carbon and nutrient standing stocks of helophyte biomass in rewetted fens. Hydrobiologia. doi:10.1007/s10750-011-0782-5

Struyf, E., W. Kotowski, S. Jacobs, S. van Damme, K. Bal, W. Opdekamp, H. Backx, D. van Pelt \& P. Meire, 2011. Tracing Si-N-P ecosystem-pathways: is relative uptake in riparian vegetation influenced by soil waterlogging, mowing management and species diversity? Hydrobiologia. doi:10.1007/s10750-011-0737-x

Trepel, M., 2007. Wetland restoration at the Society for Ecological Restoration international conference in Zaragoza, Spain. Ecological Engineering 30: 91-92.

Van Diggelen, R., A. P. Grootjans \& J. A. Harris, 2001. Ecological restoration: state of the art or state of the science. Restoration Ecology 9: 115-118.

Vymazal, J., 2011. Plants used in constructed wetlands with horizontal subsurface flow: a review. Hydrobiologia. doi: 10.1007/s10750-011-0738-9

Zak, D., C. Wagner, B. Payer, J. Augustin \& J. Gelbrecht, 2010. Phosphorus mobilization in rewetted fens: the effect of altered peat properties and implications for their restoration. Ecological Applications 20: 1336-1349. 